\title{
PERBANDINGAN TOTAL RENDEMEN DAN SKRINING ANTIBAKTERI EKSTRAK ETANOL DAUN SIRIH HIJAU (Piper betle L.) SECARA MIKRODILUSI
}

\author{
Rissa Laila Vifta ${ }^{*}$, Muhammad Andri Wansyah P.², Anita Kumala Hati ${ }^{3}$ \\ Program Studi Farmasi, Fakultas IImu Kesehatan, Universitas Ngudi Waluyo \\ Jalan Gedongsongo, Candirejo, Ungaran Barat
}

\begin{abstract}
:
The optimization of extraction procces for Green betel leaves (Piper betle L.) have been attempted. The aim of the research was to knowing the influence and the ratio of total yield on two different methods, that was using maceration and reflux method and followed by microbial antibacterial by microdilution test to show the qualitative value of MIC percentage of Green betel leaves extract against Escherichia coli and Staphylococcus aureus bacteria. The analysis was conducted descriptively for subsequent use as a basis to determined MIC percentage quantitatively.

The result of extraction with two methods showed that the highest yield was yielded in reflux process with $18.5 \%$ rendement value with the weight ratio of 1: 5 to the maceration process. Phytochemical screening shows the ethanol extract of Green betel leaves contains flavonoid, saponins, and tannins compounds that have activated as antibacterial. The results of microbial antibacterial testing showed that Green betel leaves extract had broad spectrum antibacterial activity which showed by MIC percentage in Staphylococcus aureus and Escherichia coli both reflux and maceration extract. The test results indicate that Green betel leaves (Piper betle L.) have potential as an antibacterial candidate.
\end{abstract}

Keyword : Green betel, reflux, maceration, antibacterial, microdilution

\section{Pendahuluan}

Penemuan obat penyakit infeksi khususnya infeksi bakteri merupakan hal yang banyak dikembangkan oleh para peneliti pada masa sekarang ini. Upaya penemuan obat antibakteri banyak difokuskan dalam bidang-bidang bioteknologi pemanfaatan obat alam. Pertimbangan faktor ekonomis dan keamanan yang relatif baik pada pemanfaatan obat-obatan yang berasal dari alam merupakan alasan yang paling diperhatikan dalam pelaksanaanya [1].

Sirih Hijau (Piper betle L.) merupakan salah satu tanaman herbal yang mulai mendapat perhatian ahli untuk diteliti. Sirih Hijau dipercaya memiliki khasiat herbal yang dapat dimanfaatkan oleh masyarakat, salah satunya sebagai antimikroba. Bagian tanaman Sirih Hijau yang diduga memiliki khasiat sebagai antimikroba adalah bagian daun. Beberapa penelitian menyebutkan bahwa daun Sirih Hijau dapat digunakan sebagai obat batuk, obat cacing, serta antiseptik luka [2]. Daun Sirih Hijau mengandung senyawa metabolit sekunder seperti saponin, tannin, flavonoid, terpenoid, polifenol, serta steroid yang diduga memiliki aktifitas sebagai antibakteri [2]. Beberapa langkah optimasi telah dilakukan sebagai upaya mengkaji efektifitas senyawa aktif yang berpotensi sebagai antibakteri. Salah satu langkah optimasi yang dilakukan adalah memilih metode penyarian yang sesuai dengan sifat fisik dan kimia Daun Sirih Hijau tersebut.

Metode penyarian senyawa aktif tanaman atau yang lebih dikenal dengan metode ekstraksi terdiri dari dua proses, yakni ekstraksi panas dan ekstraksi dingin [3]/2. Salah satu metode ekstraksi yang banyak dikembangkan karena faktor kemudahan adalah maserasi. Penelitian lain menyebutkan bahwa penyarian dengan metode refluks dapat meminimalkan penggunaan pelarut dengan hasil rendemen yang baik [4, 5, 6].

Berdasarkan latar belakang tersebut, peneliti melakukan optimasi ekstraksi herbal Sirih Hijau menggunakan dua metode yang berbeda dengan tujuan memperoleh hasil rendemen dan pelarutan senyawa aktif yang optimal. Selanjutnya, ekstrak yang dihasilkan dilakukan uji mikrodilusi untuk menetapkan hasil kualitatif ekstrak sebagai kandidat antibakteri. 


\section{Metode Penelitian}

\section{Alat dan Bahan}

Alat

Alat untuk ekstraksi Daun Sirih Hijau antara lain seperangkat alat refluks, Eppendorf Reference 200 $\mu \mathrm{L}$, neraca analitik And GR-300, rotary evaporator Ryela N-1000, ultrasonic cleaner WT-600-40, dan waterbath Eyela SB-1000.

Bahan

Bahan uji yang digunakan adalah daun sirih hijau (Piper betle L.) dengan spesifikasi warna hijau dari Desa Sumurrejo Kecamatan Gunungpati Kota Semarang Jawa Tengah yang sebelumnya telah dilakukan determinasi.

Bahan kimia yang digunakan antara lain $\mathrm{DMSO}, \mathrm{AlCl}_{3}, \mathrm{NaOH} 0,5 \mathrm{~N}, \mathrm{FeCl}_{3} 1 \%$, pereaksi dragendorff, pereaksi Mayer, $\mathrm{HCl}$ p.a, $\mathrm{HCl} 2 \mathrm{~N}, \mathrm{H}_{2} \mathrm{SO}_{4}$ p.a, $\mathrm{H}_{2} \mathrm{SO}_{4} 1 \mathrm{M}$, Magnesium, $\mathrm{NaCl} 10 \%$, $\mathrm{FeCl}_{3} 1 \%$, amoniak $25 \%$, nheksan, etil asetat, etanol 96\%, CMC Na 0.3\% dari Merck, Aquades dari CV. Bratachem.

\section{Prosedur Penelitian}

\section{Determinasi Tanaman Sirih Hijau (Piper betle L.)}

Tanaman Sirih Hijau (Piper betle L.) dideterminasi di Laboratorium Ekologi dan Biosistematik Jurusan Biologi Fakultas MIPA Universitas Diponogoro Semarang.

\section{Ekstraksi Daun Sirih Hijau (Piper betle L.) dengan Metode Maserasi}

Ekstraksi dengan metode maserasi diawali dengan sortasi bahan dengan tujuan untuk memisahkan kotoran-kotoran atau bahan-bahan asing sehingga dapat mengurangi jumlah pengotor yang ikut terbawa dalam bahan uji, selanjutnya dibuat simplisia. Simplisia daun sirih hijau (Piper betle L.) sebanyak 500 gram dimaserasi selama 5 hari dalam ruangan yang terlindung cahaya matahari dan dilakukan pengadukan $1 \times 24$ jam. Maserat diuapkan menggunakan rotary evaporator dengan suhu $45^{\circ} \mathrm{C}$.

\section{Ekstraksi Daun Sirih Hijau (Piper betle L.) dengan Metode Refluks}

Ekstraksi refluks merupakan suatu metode yang sering digunakan untuk mendapatkan suatu senyawa dari tumbuhan dengan penguapan pada suhu tinggi. Proses ekstraksi ini menggunakan refluks dari semula bahan serbuk kering daun sirih hijau 100 gram direfluks sebanyak 3 kali dengan perbandingan 1:6 selama 3-4 jam. Hasil yang diperoleh diuapkan untuk menghilangkan pelarut [7].

\section{Penapisan Fitokimia}

Penapisan fitokimia dilakukan untuk mengidentifikasi senyawa flavonoid, tanin, dan saponin pada ekstrak etanol Daun Sirih Hijau [8].

1) Identifikasi Flavonoid

Identifikasi flavonoid dilakukan dengan metode Wilsttater Cyanidin.

2) Identifikasi Saponin

Identifikasi saponin dilakukan dengan uji Forth

3) Identifikasi Tanin

Identifikasi tanin dilakukan dengan metode Ferri Klorida

4) Uji Bebas Etanol

Uji bebas etanol dilakukan dengan prinsip esterifikasi. Ekstrak Daun Sirih Hijau (Piper betle Linn.) diuji bebas etanol $70 \%$ dengan penambahan asam asetat dan asam sulfat pekat dan dengan pemanasan. Ekstrak dinyatakan bebas etanol bila tidak ada bau ester yang khas etanol.

\section{Pembuatan Larutan Ciprofloxacin}

Pembuatan stok awal ciprofloxacin $1 \mathrm{mg}$ yang setara dengan konsentrasi $1000 \mu \mathrm{g} / \mathrm{ml}$. Kemudian dibuat pengenceran untuk masing-masing bakteri.

\section{Uji Antibakteri Dengan Metode Mikrodilusi}

Uji aktivitas antibakteri dengan metode cara mikrodilusi dilakukan untuk mengetahui MIC (Minimum Inhibitor Concentration) atau Kadar Hambat Minimum (KHM) ekstrak Daun Sirih Hijau (Piper bettle L) terhadap bakteri Eschericia coli dan Staphylococcus aureus. MIC/KHM merupakan konsentrasi terendah dari suatu senyawa antibakteri yang dapat menghambat pertumbuhan mikroba tertentu. MIC/KHM digunakan sebagai ukuran sensitifitas mikroba terhadap suatu suatu senyawa antibakteri [9]. Pengujian dilakukan secara kualitatif menggunakan mikroplate dengan pengamatan kekeruhan. Standar kekeruhan bakteri dibandingkan dengan larutan Mcfarland standar nomor 1 yang setara dengan $3 \times 10^{8} \mathrm{cfu} / \mathrm{ml}$, kemudian dilakukan pengenceran seri $10^{-2}$ sehingga diperoleh suspensi dengan jumlah bakteri $3 \times 10^{6} \mathrm{sel} / \mathrm{ml}$ [9]. Konsentrasi ekstrak dibuat ke dalam tiga konsentrasi yang berbeda, yakni $1 \%, 3 \%$, dan $5 \%$. Indikator $\%$ 
MIC ditentukan berdasarkan timbulnya warna jernih pada mikroplate yang sudah diisi dengan Ekstrak Daun Sirih Hijau pada berbagai konsentrasi.

\section{Hasil dan Pembahasan}

\section{Determinasi Tanaman Sirih Hijau}

Hasil determinasi menunjukkan bahwa tanaman yang digunakan dalam penelitian adalah tanaman Sirih Hijau (Piper betle Linn) karena mempunyai ciri fisik yang sesuai. Tanaman Sirih Hijau (Piper betle Linn) memiliki batang panjang 5-15 m, daun berseling atau tersebar, bertangkai, pangkal daun berbentuk jantung dan ujung meruncing $[10,11]$. Determinasi dilakukan dengan tujuan untuk mengidentifikasi tumbuhan yang akan diteliti berdasarkan ciri-ciri fisik sehingga kesalahan dalam pengambilan tanaman yang akan diteliti dapat dihindari.

Adapun klasifikasi tanaman sirih hijau dijelaskan sebagai berikut :

Kingdom : Plantae (Tumbuhan)

Subkingdom : Tracheobionta (Berpembuluh)

Superdivisio : Spermatophyta (Menghasilkan biji)

Divisio : Magnoliophyta (Berbunga)

Kelas : Dicotylodoneae

Sub-kelas : :

Ordo : Piperales

Family : Piperaceae

Genus : : Piper

Spesies $\quad$ : Piper betle L. (Sirih, Sirih Hijau)

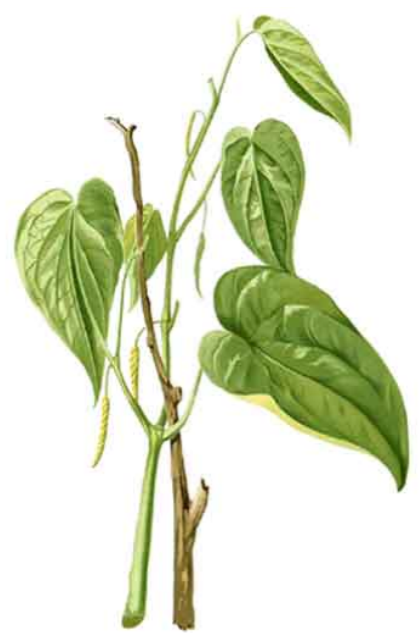

Gambar 1. Morfologi Daun Sirih Hijau (Piper betle L.) [11]

\section{Penapisan Fitokimia}

Pengujian senyawa aktif Ekstrak Etanol Daun Sirih Hijau (Piper betle Linn) dilakukan secara kualitatif untuk mengidentifikasi adanya kandungan flavonoid, tanin, dan saponin yang memiliki potensi sebagai antibakteri. Hasil penapisan fitokimia disajikan pada Tabel 1.

\begin{tabular}{lllc} 
Zat aktif & Identifikasi & Hasil uji & Keterangan \\
\hline Flavonoid & $\begin{array}{l}0,1 \text { sampel + metanol, sampai } \\
\text { terendam } \rightarrow \text { dipanaskan, filtrat + } \\
\mathrm{H}_{2} \mathrm{SO}_{4}\end{array}$ & Merah & + \\
& & & + \\
\end{tabular}




\begin{tabular}{llll}
\hline Saponin & Ekstrak + air, gojog $\rightarrow$ buih $+\mathrm{HCl}$ pekat & Berbuih & + \\
\hline Tanin & Ekstrak $+\mathrm{FeCl}_{3} 1 \%$ & Hitam kuat & + \\
\hline $\begin{array}{l}\text { Bebas } \\
\text { etanol } \mathbf{7 0} \%\end{array}$ & $\begin{array}{l}\text { Ekstrak }+\mathrm{H}_{2} \mathrm{SO}_{4} \text { pekat }+\mathrm{CH}_{3} \mathrm{COOH}, \\
\text { dipanaskan }\end{array}$ & $\begin{array}{l}\text { Tidak tercium bau ester } \\
\text { yang khas }\end{array}$ & + \\
\hline
\end{tabular}

Tabel 1. Hasil uji identifikasi senyawa aktif Ekstrak Etanol Daun Sirih Hijau

Hasil penapisan fitokimia menunjukkan bahwa ekstrak Daun Sirih Hijau mengandung senyawa flavonoid, saponin, dan tanin. Adanya senyawa flavonoid diidentifikasi dengan uji wilstater sianidin yang menunjukkan adanya perubahan warna dari kuning kehijauan menjadi warna merah yang menandakan terjadinya pembentukan senyawa kalkon. Senyawa kalkon diidentifikasi mempunyai aktivitas sebagai antibakteri, antiinflamasi, dan antioksidan [12].

Adanya senyawa saponin dalam ekstrak etanol Daun Sirih Hijau (Piper betle Linn) diidentifikasi dengan uji forth. Hasil positif ditandai dengan terbentuknya buih yang merupakan karakteristik saponin [13,14]. Senyawa tanin diidentifikasi dengan pereaksi $\mathrm{FeCl}_{3}$ yang menunjukkan hasil positif warna hitam yang menandakan pembentukan tanin terhidrolisis.

Uji bebas etanol dilakukan sebagai upaya pemastian tidak adanya pelarut etanol pada ekstrak yang dihasilkan. Keberadaan etanol dapat mempengaruhi pengujian antibakteri dikarenakan gugus aktif pada etanol sendiri bersifat toksik terhadap bakteri.

\section{Perhitungan Total Rendemen}

Hasil perhitungan total rendemen memberikan hasil yang berbeda pada dua metode ekstraksi yang dilakukan terhadap daun Sirih Hijau. Rendemen ekstrak diperoleh berdasarkan perbandingan berat ekstrak yang diperoleh denggan berat simplisia yang digunakan dikalikan dengan $100 \%$ sesuai yang dicantumkan pada persamaan (1)

$$
\text { Rendemen }=\frac{(\text { BobotEkstrak })}{(\text { BobotSimplisia })} \times 100 \%
$$

Perhitungan total rendemen kedua metode ekstraksi disajikan pada Tabel 2. Hasil rendemen ekstrak daun Sirih Hijau yang diekstraksi dengan metode refluks diperoleh sebanyak 18.5 gram dari 100 gram bobot simplisia awal (18.5\%). Hasil ini lebih tinggi dibandingkan dengan ekstrak hasil maserasi (14.16\%) dengan presentase bobot simplisia pada proses refluks sebesar seperlima bagian bobot simplisia pada metode maserasi.

\begin{tabular}{llll}
\hline Metode Ekstraksi & Bobot Simplisia & $\begin{array}{l}\text { Bobot Ekstrak } \\
\text { Kental }\end{array}$ & Rendemen \\
\hline Maserasi & $500 \mathrm{~g}$ & $70,8 \mathrm{~g}$ & $14,16 \%$ \\
\hline Refluks & $100 \mathrm{~g}$ & $18.5 \mathrm{~g}$ & $18.5 \%$ \\
\hline
\end{tabular}

Tabel 2. Hasil perhitungan total rendemen ekstrak etanol Daun Sirih Hijau

Besar kecilnya nilai rendemen merupakan parameter yang menentukan keberhasilan suatu proses ekstraksi. Besarnya rendemen yang diperoleh pada proses ekstraksi juga menggambarkan jumlah penarikan senyawa aktif pada zat. Efektifitas proses ekstraksi dipengaruhi oleh beberapa faktor antara lain jenis pelarut, ukuran partikel, metode ekstraksi, dan lama proses ekstraksi [15]. Metode refluks melibatkan pemanasan pada prosesnya, sehingga penyarian senyawa aktif menjadi lebih optimal. Semakin tinggi suhu ekstraksi, proses penyerapan pelarut ke dalam bahan menjadi semakin mudah, sehingga sampel akan terekstrak semakin banyak [5]. Selain adanya penambahan suhu, pada proses refluks pelarut yang digunakan tetap segar sehingga tidak terjadi kejenuhan, sehingga kemampuan pelarut dalan menarik senyawa aktif daun Sirih Hijau meningkat [16].

\section{Hasil Uji Antibakteri Dengan Metode Mikrodilusi}

Uji aktifitas antibakteri dilakukan menggunakan metode mikrodilusi sesuai standar CLSI. Pengujian dilakukan terhadap bakteri Staphylococcus aureus dan Escherichia coli dengan tiga kali perulangan dengan tujuan memperoleh rerata yang optimal. Kontrol positif menggunakan ciprofloxacin dan kontrol negatif menggunakan DMSO. Penentuan MIC dilakukan secara visual kualitatif sebagai skrining awal pengujian antibakteri dan hasilnya digunakan sebagai dasar dalam penentuan MBC (mínimum bactericidal 
concentration) secara kuantitatif dengan metode TPC (Total Plate Count). Hasil uji antibakteri ekstrak etanol daun Sirih Hijau terhadap Staphylococcus aureus dan Escherichia coli ditunjukkan pada Tabel 3.

\begin{tabular}{|c|c|c|c|c|c|c|c|c|}
\hline \multirow{2}{*}{$\begin{array}{c}\text { Jenis } \\
\text { Ekstraksi }\end{array}$} & \multirow{2}{*}{$\begin{array}{c}\text { No } \\
\text { Tabung }\end{array}$} & \multirow{2}{*}{ Konsentrasi } & \multicolumn{3}{|c|}{ Staphylococcus aureus } & \multicolumn{3}{|c|}{ Escherichia coli } \\
\hline & & & $\operatorname{Rep} 1$ & Rep 2 & Rep 3 & $\operatorname{Rep} 1$ & Rep 2 & Rep 3 \\
\hline \multirow{6}{*}{ Refluks } & 1 & $1 \%$ & + & + & + & + & + & + \\
\hline & 2 & $3 \%$ & + & + & + & + & + & - \\
\hline & 3 & $5 \%$ & + & - & - & - & - & - \\
\hline & 4 & Kontrol M & + & + & + & + & + & + \\
\hline & 5 & Kontrol Positif & - & - & - & - & - & - \\
\hline & 6 & Kontrol Negatif & + & + & + & + & + & + \\
\hline \multirow{2}{*}{$\begin{array}{c}\text { Jenis } \\
\text { Ekstraksi }\end{array}$} & \multirow{2}{*}{$\begin{array}{c}\text { No } \\
\text { Tabung }\end{array}$} & \multirow{2}{*}{ Konsentrasi } & \multicolumn{3}{|c|}{ Staphylococcus aureus } & \multicolumn{3}{|c|}{ Escherichia coli } \\
\hline & & & Rep 1 & $\operatorname{Rep} 2$ & Rep 3 & Rep 1 & Rep 2 & Rep 3 \\
\hline \multirow{6}{*}{ Maserasi } & 1 & $1 \%$ & + & + & + & + & + & + \\
\hline & 2 & $3 \%$ & + & + & + & + & + & + \\
\hline & 3 & $5 \%$ & + & + & - & - & - & - \\
\hline & 4 & Kontrol M & + & + & + & + & + & + \\
\hline & 5 & Kontrol Positif & - & - & - & - & - & - \\
\hline & 6 & Kontrol Negatif & + & + & + & + & + & + \\
\hline
\end{tabular}

Tabel 3. Hasil pegujian antibakteri ekstrak etanol Daun Sirih Hijau pada Staphylococcus aureus dan Escherichia coli

Keterangan :

Tanda positif (+) : Menunjukkan adanya pertumbuhan bakteri

Tanda negatif $(-) \quad$ : Menunjukkan tidak adanya pertumbuhan bakteri

Kontrol M

Kontrol (+)

Kontrol (-)

: Media

: Ciprofloxacin

: DMSO

Hasil uji antibakteri yang diperoleh dari pengamatan kekeruhan menunjukkan bahwa ekstrak hasil refluks menunjukkan zona jernih pada konsentrasi 5\% untuk Staphylococcus aureus, serta konsentrasi 3\% dan 5\% untuk Escherichia coli (Gambar 2). Berbeda dengan ekstrak hasil refluks, daun Sirih Hijau yang diekstrak dengan maserasi memberikan sedikit zona jernih pada konsentrasi $5 \%$ untuk Staphylococcus aureus, serta zona jernih penuh pada konsentrasi 5\% untuk Escherichia coli.

S. aureus

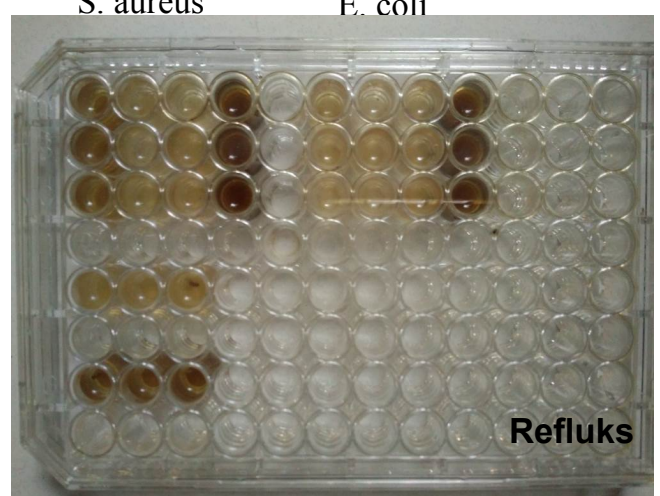

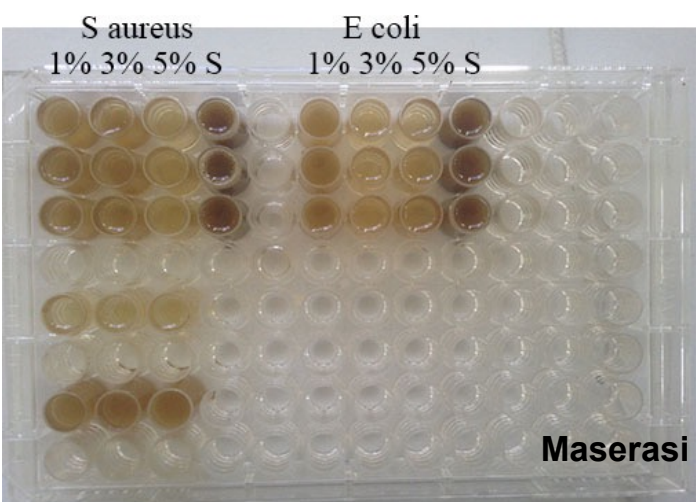

Gambar 2. Hasil pengamatan visual uji antibakteri ekstrak etanol daun Sirih Hijau dengan metode mikrodilusi 
Perbedaan hasil uji antibakteri pada kedua ekstrak daun Sirih Hijau menunjukkan adanya pengaruh metode penyarian pada aktifitas penghambatan bakteri. Penarikan senyawa aktif yang dilakukan secara refluks menunjukkan nilai MIC (mínimum inhibitor concentration) yang lebih kecil dibandingkan maserasi. Adanya penambahan suhu yang tinggi pada proses refluks dapat meningkatkan desorpsi senyawa aktif dari tanaman, sehingga senyawa yang tertarik lebih banyak dan aktifitas antibakteri meningkat [16]. Hasil uji antibakteri pada Tabel 3 juga menunjukkan bahwa ekstrak daun Sirih Hijau dapat menghambat pertumbuhan bakteri Staphylococcus aureus (gram positif) dan Escherichia coli (gram negatif). Hasl tersebut menunjukkan bahwa ekstrak etanol daun Sirih Hijau memiliki spektrum yang luas (broad spectrum) sebagai penghambat pertumbuhan bakteri. Penghambatan bakteri terlihat dari nilai MIC yang ditunjukkan kedua ekstrak baik dengan metode refluks ataupun maserasi.

Besar kecilnya nilai MIC (mínimum inhibitor concentration) pada ekstrak hasil refluks maupun maserasi dapat dipengaruhi oleh faktor lain, yakni kinerja senyawa aktif dalam penghambatan bakteri. Bakteri gram positif dan negatif memiliki struktur yang berbeda, sehingga proses penghambatan yang terjadi juga berbeda. Dinding sel Staphylococcus aureus yang merupakan bakteri gram positif mengandung lapisan peptidoglikan yang lebih tebal serta polisakarida yang disebut asam teikoat. Berbeda dengan bakteri gram positif, dinding sel Escherichia coli mengandung lebih sedikit peptidoglikan serta memiliki lapisan lipopolisakarida [17]. Perbedaan struktur inilah yang mempengaruhi perbedaan mekanisme antibakteri pada kedua ekstrak, sehingga nilai MIC atau kadar hambat mínimum yang dihasilkan juga berbeda.

Aktifitas antibakteri pada ekstrak etanol Daun Sirih Hijau sangat dipengaruhi oleh keberadaan senyawa aktif flavonoid, saponin,dan tanin yang masing-masing memiliki mekanisme antibakteri yang berbeda. Senyawa flavonoid menghambat pertumbuhan bakteri dengan jalan perusakan membran sel melalui pembentukan senyala kompleks dengan protein ektraseluler [18]. Aktifitas lain dari flavonoid yang dapat menghambat bakteri adalah melalui jalur metabolisme energi [19].

Senyawa aktif lain yang berpotensi sebagai antibakteri adalah saponin. Saponin memiliki jalur yang berbeda dalam penghambatan bakteri, yakni dengan jalan mengganggu kestabilan sitoplasma sehingga sitoplasma bocor dan mengakibatkan kematian sel [20]. Berbeda dengan flavonoid dan saponin, tanin memiliki aktifitas antibakteri dengan jalan menonaktifkan adhesin sel mikroba, menonaktifkan enzim, serta bekerja pada polipeptida dinding sel. Adanya tanin pada dinding sel, dapat mengakibatkan sel bakteri lisis sehingga sel bakteri akan mati $[21,20]$. Keberadaan metabolit sekunder pada ekstrak etanol Daun Sirih Hijau saling bekerja secara sinergis sesuai dengan mekanisme kerja masing-masing dalam penghambatan aktifitas bakteri. Sehingga, Daun Sirih Hijau (Piper betle Linn) berpotensi sebagai kandidat antibakteri.

\section{Kesimpulan}

Penyarian atau proses ekstraksi pada Daun Sirih Hijau (Piper betle L.) yang dilakukan secara refluks memberikan hasil total rendemen yang lebih signifikan sebesar $18,5 \%$ dibandingkan dengan metode maserasi tanpa mempengaruhi fungsi dan hasil penapisan senyawa aktif pada Daun Sirih Hijau. Hasil skrining antibakteri menunjukkan bahwa ekstrak etanol daun Sirih Hijau bersifat broad spectrum atau memiliki spektrum luas sebagai antibakteri yang ditunjukkan dengan nilai MIC pada kedua ekstrak hasil uji. Ekstrak hasil refluks menunjukkan nilai MIC pada konsentrasi $5 \%$ untuk $S$. aureus serta $3 \%$ dan $5 \%$ untuk E.coli, sedangkan ekstrak hasil maserasi memberikan penghambatan yang lebih lemah dengan nilai MIC lebih besar dibandingkan refluks.

\section{Penghargaan}

Ucapan terima kasih disampaikan kepada Lembaga Penelitian dan Pengadian Kepada Masyarakat (LPPM) Universitas Ngudi Waluyo yang telah memberikan fasilitas pendanaan Internal demi tercapainya penelitian ini.

\section{Daftar Pustaka}

[1] A. Sartinah, "Isolasi dan Identifikasi Senyawa Antibakteri Dari Daun Petai Cina," Tesis. Fakultas Farmasi Sains dan Teknologi UGM, Yogyakarta, 2011.

[2] S. Kursia, J.S.Lebang, B. Taebe, A. Burhan, Wa O.R. Rahim, Nursamsiar. "Uji Aktifitas Antibakteri Ekstrak Etilasetat Daun Sirih Hijau (Piper betle L.) terhadap Bakteri Stapylococcus epidermidis", Ind. J. of Pharmaceutical Sci. and Tech.3(2):72-77. 2016.

[3] A. N. Kristianti. Buku Ajar Fitokimia, Airlangga University Press, Surabaya, 2008.

[4] A. B. Putra, N. W. Bogoriani, N. P. Diantariani, N. L. U Sumadewi," Ekstraksi Zat Warna Alam Dari Bonggol Tanaman Pisang (Musa Paradiasciaca L.) Dengan Metode Maserasi, Refluks, Dan Sokletasi, "Jurusan Kimia Fmipa Universitas Udayana, Bukit Jimbaran, 2013.

[5] E., Pratiwi, "Perbandingan Metode Maserasi, Remaserasi, Perkolasi dan Reperkolasi dalam Ekstraksi Senyawa Aktif Andrographolide dari Tanaman Sambiloto (Andrographis paniculata (Burm.F.) Nees)" Skripsi, Institut Pertanian Bogor, Bogor, 2010. 
[6] M.S., Mohan, Khanam, B.G. Shivananda, "Optimization of Extraction of Andrographolide from Andrographis paniculata and its Comparison with Refluxation Extraction Method," Journal of Pharmacognosy and Phytochemistry, Vol. 2. 342-348, 2013.

[7] N. P. L., Laksmiani, Susanti, N.M.P., Widjaja, I. N. K.., Rismayanti, A. A. M. I., Wirasuta IM.A.G. "Pengembangan Metode Refluks untuk Ekstraksi Andrografolid dari Herba Sambiloto

(Andrographis paniculata (Burm.f.) Nees)." Jurusan Farmasi Fakultas Matematika dan Ilmu Pengetahuan Alam Universitas Udayana, 2011.

[8] J.A.H. Sheela, "Qualitative Analysis Of Secondary Metabolites Of The Plant Clematis Gouriana," Int. Journal Innovative Research in Sci Eng, and Tech. Vol. 2 (6) : 2356-2358, 2013.

[9] T. Juwitaningsih, Y. M. Syah, L. D. Juliawaty, "Aktifitas Antibakteri Dari Ekstrak Alphina malaccensis (Burm.f) Roxb. Prosiding Seminar Nasional Kimia dan Pendidikan Kimia VI. 495-500, 2014

[10] Backer and V. D. Brink.1968. Flora of Java vol.I-III. Wolters - Noordhoff NV - Groningen. The Netherlands.

[11] V., Dwivedi and Tripathi, S., Review Study on Potential Activity of Piper betle L., Journal of Pharmacognosy and Phytochemistry. 3(4): 93-98, 2014.

[12] G.E. Treas and Evans, W.C., Pharmacognosy. 11th edn. Brailliar Tiridel Can. Macmillian publishers. 1989.

[13] E. Pelegrini, Carucci, M. G., Campanella, A., Lorenzini, G., Nali, C., "Ozone Stress In Melissa officinalis Plants Assessed by Photosynthetic Function", Environ. Exp.Bot. 73, 94-101. 2011.

[14] S., Ganiswarna. 1995. Farmakologi dan Terapi, Edisi 4. UI press. Jakarta

[15] N., Salamah, M. Rozak, M. A. Abror, "Pengaruh Metode Penyarian Terhadap Kadar Alkaloid Total Daun Jembirit (Tabernaemontana sphaerocarpa BL.) Dengan Metode Spektrofotometri Visibel, “, Pharmaciana. Vol. 7 No. 1. 113-122, Mei 2017.

[16] T., Jain., Jain V., Pandey, R. Vyas, A., Shukla, S.S. Microwave Assisted Extraction for Phytoconstituents-An overview. Asian Journal Research Chemistry. 1(2), 19-25, 2009.

[17] C. Pagliarulo, V.D. Vito, G. Picariello, R. Colicchio, G. Pastore, P. Salvatore, M.G. Volpe, "Inhibitory Effect Of Pomegranate (Punica Granatum L.) Polyphenol Extracts On The Bacterial Growth And Survival Of Clinical Isolates Of Pathogenic Staphylococcus aureus and Escherichia coli”, Food Chem., Vol. 190, 824-831, 2016.

[18] M.C. Nuria, A. Faizatun., Sumantri, "Uji Antibakteri Ekstrak Etanol Daun Jarak Pagar (Jatropha cuircas L) terhadap Bakteri Staphylococcus aureus ATCC 25923, Escherichia coli ATCC 25922, dan Salmonella typhi ATCC 1408," Jurnal IImu - ilmu Pertanian. 5: 26 - 37, 2009.

[19] T.P.T. Cushnie and A.J. Lamb, Antimicrobial Activity of Flavonoids. International Journal of Antimicrobial Agents. 26: 343 - 356. 2005.

[20] S.J. Cavalieri,, I.D. Rankin., R.J. Harbeck., R.S. Sautter., Y.S. McCarter., S.E. Sharp., J.H. Ortez., C.A. Spiegel, Manual of Antimicrobial Susceptibility Testing. American Society for Microbiology, USA, 2005.

[21] F.P. Sari,, dan S. M. Sari, Ekstraksi Zat Aktif Antimikroba dari Tanaman Yodium (Jatropha multifida Linn) sebgai Bahan Baku Alternatif Antibiotik Alami, Fakultas Teknik Universitas Diponegoro, Semarang, 2011. 